\title{
Bronchial Stricture
}

National Cancer Institute

\section{Source}

National Cancer Institute. Bronchial Stricture. NCI Thesaurus. Code C78226.

Narrowing of a bronchial tube. 